\title{
nordon
}

\section{Sameiginlegar áskoranir og norrænt notagildi}

Samstarfsáætlun Norrænu rádherranefndarinnar um vinnumál 2013-2016

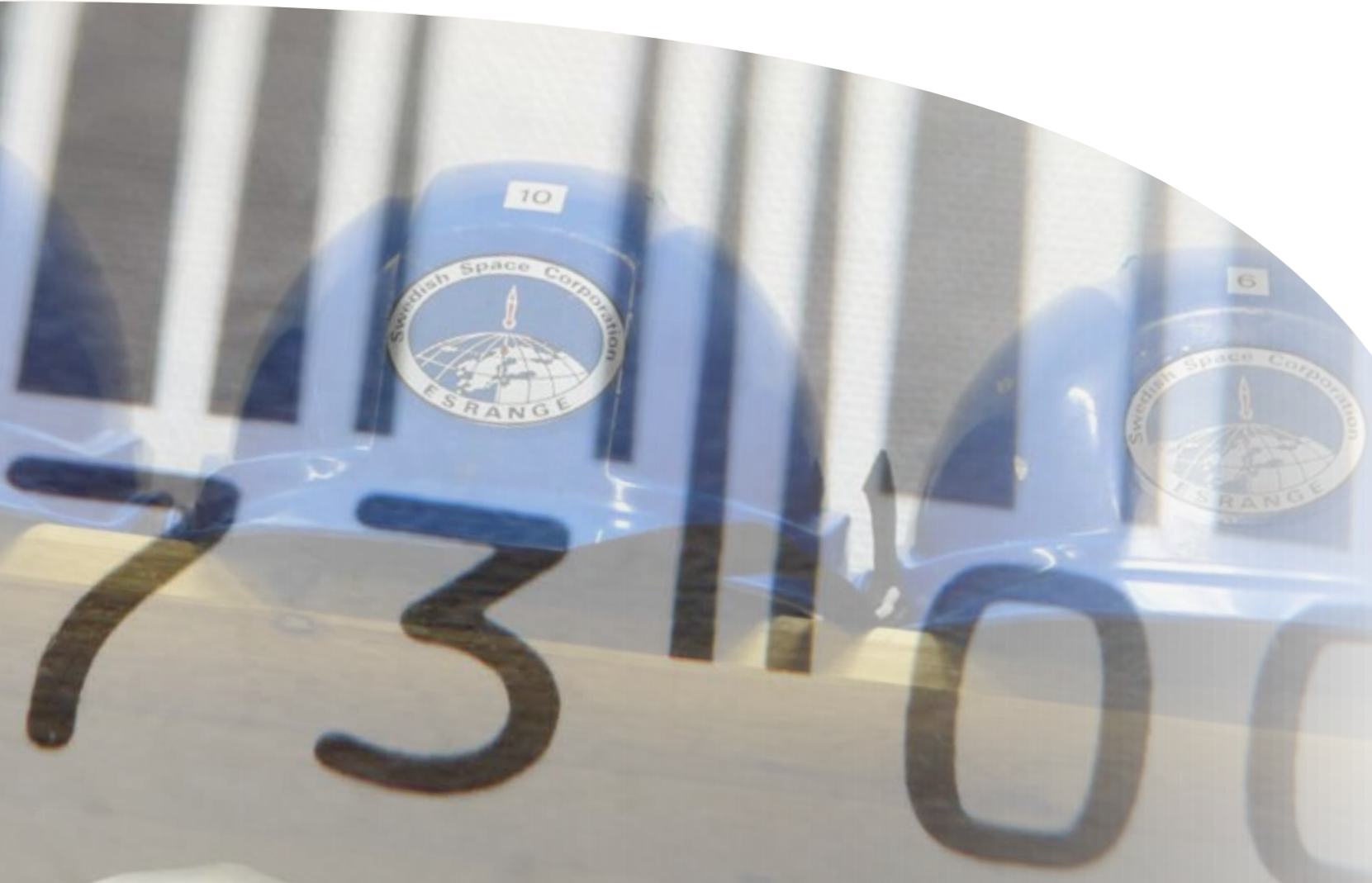





\section{Sameiginlegar áskoranir og norrænt notagildi}

Formáli 3

$\begin{array}{ll}\text { Samantekt } & 7\end{array}$

$\begin{array}{lr}\text { Inngangur } & 9\end{array}$

Megináskoranir á sviði vinnumála 10

Forgangsmál og markmið á tímabilinu $\quad 12$

- Vinnu- og vinnumarkadsmál 12

- Vinnuvernd og vinnuréttur 14

- Forgangsmál allra sviða að medtöldu afnámi stjórnsýsluhindrana $\quad 17$

$\begin{array}{ll}\text { Rammar samstarfsins } & 18\end{array}$ 


\section{Sameiginlegar áskoranir og norrænt notagildi}

Samstarfsáætlun Norrænu rádherranefndarinnar um vinnumál 2013-2016

ISBN 978-92-893-2485-4

http://dx.doi.org/10.6027/ANP2013-715

ANP 2013:715

C Norræna rádherranefndin 2013

Umbrot: Jette Koefoed

Ljósmyndir: Magnus Fröderberg bls. 8, 12, 14;

ImageSelect bls. 11, 13; Johannes Jansson bls. 15;

Karin Beate Nøsterud bls. 16

Kápumynd: ImageSelect; Johannes Jansson/NMR

Upplag: 100

Prentun: Scanprint as

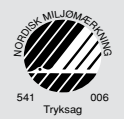

www.norden.org/is/utgafa

Printed in Denmark

\section{Norrænt samstarf}

Norræna samstarfið er eitt umfangsmesta svæðasamstarf í heiminum. Samstarfið nær til Danmerkur, Finnlands, Íslands, Noregs og Svípjódar auk Álandseyja, Færeyja og Grænlands.

Norræna samstarfið er pólitískt, efnahagslegt og menningarlegt og skiptir miklu í evrópsku og alpjódlegu samstarfi. Í norrænu samstarfi er unnið að pví að styrkja stöðu Norðurlanda í sterkri Evrópu.

Með norrænu samstarfi er unnið að pví að efla norræna og svæðisbundna hagsmuni í alpjódlegu umhverfi. Sameiginleg gildi landanna styrkja stöðu Norðurlanda og skipa peim meðal peirra svæða í heiminum par sem nýsköpun og samkeppnishæfni er mest.

\section{Norræna rádherranefndin}

Ved Stranden 18

DK-1061 København K

Sími (+45) 33960200

\section{www.norden.org}




\section{Formáli}

Samstarfsáætlun rádherranefndar um vinnumál hefur à geyma stefnumótun og áherslur í formlegu samstarfi norrænu ríkisstjórnanna um vinnumál fyrir árin 2013-2016.

Mörg sömu langtímaviðfangsefni blasa við á vinnumörkuðum Norðurlanda vegna hnattvæðingar og breytinga á aldurssamsetningu en einnig má búast við að hagsveiflur og jafnvel kreppuástand hafi í för med sér verkefni til skemmri tíma. Pá mun reyna á samkeppnishæfni, styrk og samheldni norræna velferdarkerfisins.

Samstarfsáætlun rádherranefndar um vinnumál felur í sér helstu markmið samstarfsins en öll eiga pau ad gera norrænu löndin betur í stakk búin til ad takast á vid fyrrnefndar áskoranir í vinnumálum. Meðal annars parf að fjölga vinnandi fólki og auka hæfni pess í samræmi við parfir vinnumarkaðar, draga úr atvinnuleysi peirra sem standa höllum fæti og grípa til adgerda gegn langtímaatvinnuleysi - einkum ungs fólks. Tryggja ber gott vinnuumhverfi og sjálfbæra nýtingu mannauds, koma í veg fyrir félagslegt undirbod og mismunun á vinnumarkadi, skapa jafnvægi milli verndar launpega og kröfu um sveigjanleika og efla norrænt samstarf um alpjódlegar reglugerðir. Mikilvægt forgangsmál er afnám stjórnsýsluhindrana á norrænum vinnumarkadi og ad koma í veg fyrir ad nýjar hindranir myndist. Í áætluninni kemur fram hvaða samningar pað eru sem samstarfid hvílir á.

Par vil ég einkum nefna Samning um sameiginlegan norrænan vinnumarkað. Allt frá árinu 1954 hefur samningurinn gert norrænum borgurum kleift aðे starfa og setjast ad í norrænum nágrannaríkjum. Á tímabili áætlunarinnar verða 60 ár liðin frá pví ad̀ sameiginlegur vinnumarkaður Norðurlanda varð að veruleika en norrænn vinnumarkaður er einn sampættasti svædisbundni vinnumarkadur í heimi. Við Norðurlandabúar höfum fulla ástæðu til að vera hreyknir af pví!

Pað er von mín ad norrænt samstarf um vinnumál sem og á ödrum sviðum haldi áfram ad lada fram nýskapandi og framsæknar lausnir.

Halldór Ásgrímsson

Framkvæmdastjóri

Norrænu rádherranefndarinnar 

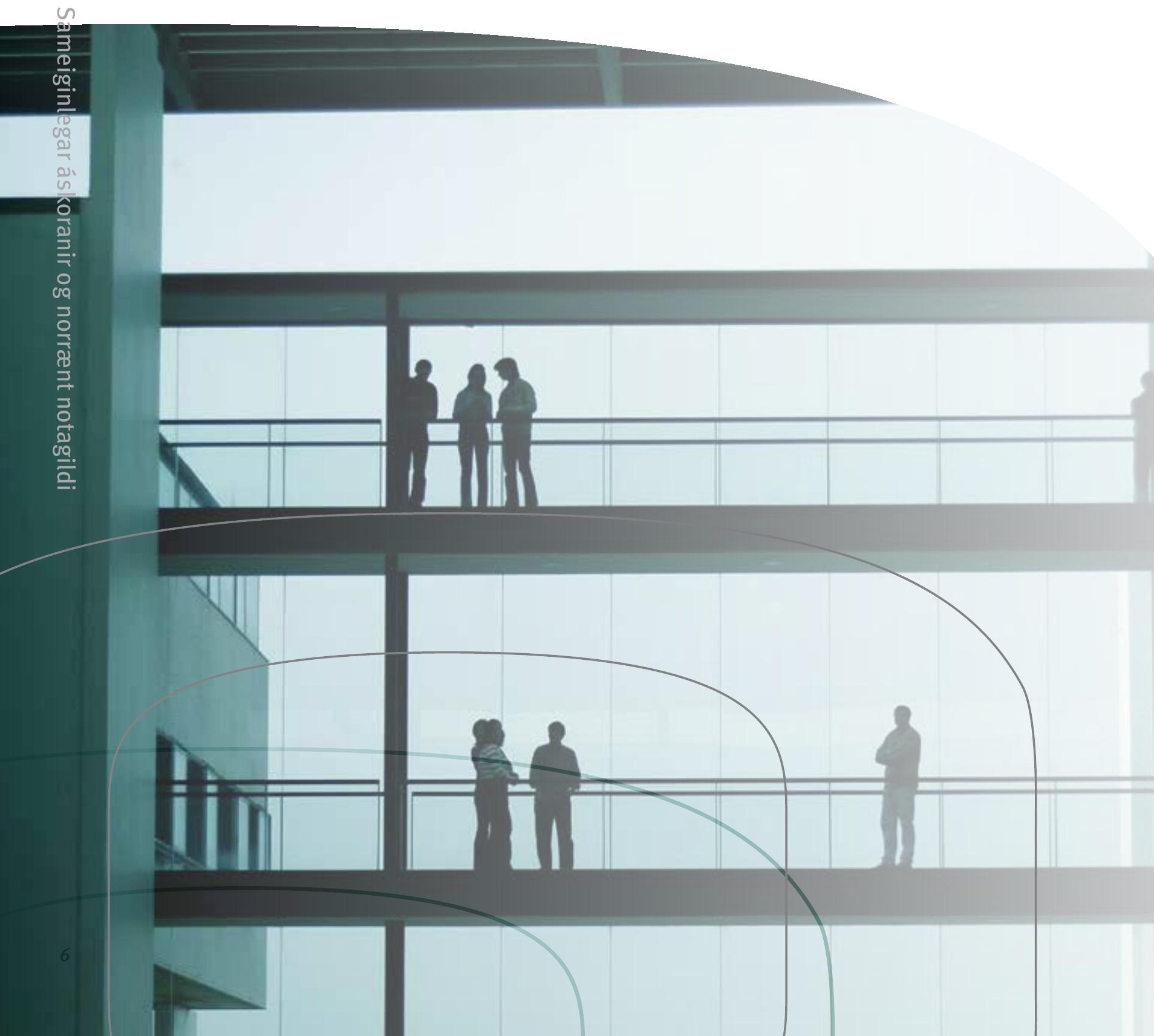


\section{Samantekt}

Samstarfsáætlunin markar stefnu í formlegu samstarfi norrænu ríkisstjórnanna á svidi vinnumála fyrir tímabilið 2013-2016. Á pessu tímabili mun áherslan beinast ad langtímaverkefnum í kjölfar

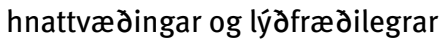
próunar en mun einnig eftir pörfum beinast að hagsveiflum sem koma upp á tímabilinu.

Sem fyrr felst samstarfið fyrst og fremst í midlun reynslu og upplýsinga innan rádherranefndar um vinnumál um adgerdir í

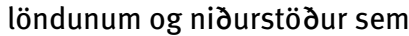
snerta sameiginlegar áskoranir. Samstarfið felst einnig í mikilvægu tengslanetstarfi meðal starfsmanna í stjórnsýslu á svidi vinnumála á Norðurlöndum. Norræn reynsluog upplýsingamidlun, myndun tengslaneta og samhæfing vegna aðgerða og samninga á vettvangi Evrópusambandsins (ESB) ásamt innleiðingu ESB-tilskipana eru einnig midlægir pættir í samstarfinu.

Megináhersla í samstarfi á vinnuog vinnumarkaðssviði er á fjölgun starfa, aukid atvinnustig og á pad að draga úr atvinnuleysi kvenna og karla sem er til komið vegna skipulagsbreytinga. Markmiðið er að styrkja fjárhagsstödu ríkjanna og sjálfbærni norrænu velferdarsamfélaganna í framtídinni og ad efla pátttöku jadarhópa í samfélaginu. Markmiðin eru ad virkja vinnuafl í löndunum, styrkja samræmi frambods og eftirspurnar eftir vinnuafli, efla símenntun með hliðsjón af pörfum vinnumarkaðarins, gera norrænu löndin eftirsóknarverð fyrir vinnuafl frá löndum utan ESB og Evrópska efnahagssvædisins (EES) sem eftirspurn er eftir, efla samhæfingu stjórnvalda sem málið varðar og að sporna gegn atvinnuleysi peirra sem minna mega sín og langtímaatvinnuleysi. Baráttan gegn atvinnuleysi ungs fólks er mikilvæg og mikið forgangsmál.

Eitt meginforgangsmál samstarfs á vinnuverndarsviði er ad efla öryggi, heilsu og velferdá vinnustöðum bæði fyrir konur og karla. Markmiðið er að skapa eftirsóknarverda vinnustadi sem eru hvetjandi og fyrir alla par sem áhersla er lögð á að fyrirbyggja starfstengd líkamleg og sálræn heilbrigdisvandamál. Hafa skal hliðsjón af alpjódlegum samningum og löggjöf ESB. Markmiðið er ad efla gott vinnuumhverfi á vinnustöðum, próa enn frekar vinnuvernd og -eftirlit, koma í veg fyrir óásættanleg starfskjör, 



\section{Inngangur}

Norrænt samstarf á vinnumálasviði á sér langa sögu. Á pað bæði við um formlegt samstarf á vettvangi Norrænu rádherranefndarinnar og Norðurlandaráds og um óformlegt samstarf landanna. Vegna sameiginlegra norrænna gilda og pess aə margt er sameiginlegt med norrænu löndunum getum við lært af reynslu hvers annars og samhæft sjónarmið par sem pað á við og pad felur i sér norrænt notagildi, p.e. á peim sviðum par sem löndin geta nád betri árangri saman en hvert fyrir sig.

Markmið samstarfsáætlunar pessarar er að marka stefnu fyrir formlegt samstarf norrænu ríkisstjórnanna á vettvangi rádherranefndar um vinnumál á tímabilinu 2013-2016. Undir samstarfið heyra vinnu- og vinnumarkaðssvið og vinnuverndar- og vinnuréttarsvið.

I áætluninni er lögd áhersla á markvisst norrænt samstarf um verkefni sem fela í sér norrænt notagildi og efla um leið tækifæri norrænu landanna til að takast á við sameiginlegar áskoranir.
Megininntak samstarfsins mun sem fyrr felast í að gera úttektir, greina og ræda pad sem líkt er og ólíkt í aðgerðum og niðurstöðum norrænu landanna varðandi sameiginlegar áskoranir. Í gegnum petta formlega samstarf verða einnig til mikilvæg tengslanet meðal norrænna stjórnvalda á vinnumálasviði sem getur nýst löndunum vel í tilvikum sem upp kunna að koma.

Áhersla samstarfsins á pessu tímabili mun einkum beinast að fjölda markmiða um pað hvernig unnt sé að bregðast við langtímaáskorunum sem norrænn vinnumarkaður stendur gagnvart vegna hnattvæðingar og lýdpróunar. Áherslurnar eru pó sveigjanlegar sem er nauðsynlegt pegar bregðast parf við áskorunum sem tengjast hagsveiflum sem geta komið upp á tímabilinu.

\section{Samstarfið verður útlistað nánar í} formennskuáætlunum landanna fyrir sviðið og árlegum starfsáætlunum fyrir hvert samstarfssvið fyrir sig. 


\section{Megináskoranir á sviði vinnumála}

Vinnu- og vinnumarkadsmál gegna mikilvægu hlutverki i próun norrænu velferðarsamfélaganna, atvinnulífs og einstaklinga. Áhrifa áskorana í vinnu- og vinnumarkadsmálum gætir á mörgum stigum samfélaga á Norðurlöndunum. Ríkisstjórnir norrænu landanna purfa jafnódum að taka afstöðu til pess hvernig beita megi stefnumörkun á vinnuog vinnumarkaðssviði og samstarfi við adila vinnumarkaðarins til að bregðast við áskorunum vinnumarkaðarins til að efla hagvöxt og atvinnu. Vegna norræns samstarfs á sviði vinnumála eiga ríkisstjórnirnar aðgengi að gagnlegum upplýsingum og hugmyndum sem nýtast í pví starfi.

Próun vinnumarkadar í norrænu löndunum verður fyrir síauknum áhrifum langtímapróunar, en par skipta mestu pættirnir hnattvæðing og lýdpróun. Pessum páttum fylgja î senn ný tækifæri og nýjar áskoranir. Jafnframt gætir mikilla áhrifa hagsveiflna á vinnumarkaði sem parf ad bregðast hratt við.

Vegna hnattvædingar mun pad áfram vera megináskorun til lengri tíma ad efla sveigjanleika og samkeppnishæfni norrænna vinnumarkaða. Pað mun auka möguleika á ad jafna út fækkun starfa vegna skipulagsbreytinga, p.m.t. á sviðum sem verða undir í aukinni samkeppni á heimsmarkaði, og bjóda fram vinnuafl sem hefur pá hæfni sem eftirspurn er eftirá hagvaxtarsviðum. Frá hnattrænu sjónarhorni verður vinnuaflið æ hreyfanlegra. Pví fylgja auknar kröfur um að tryggja jafnvægi milli launpegaverndar og sveigjanleika og að vinnuaflið búi yfir peirri hæfni sem eftirspurn er eftir á vinnumarkaði.

Hnattvæðingin eykur einnig samkeppni um pá hæfustu á heimsmarkadi. Megináskorunin er að efla og kynna kosti pess að starfa og búa í norrænu löndunum, p.m.t. að gera norræna vinnumarkadi enn eftirsóknarverðari meðal annars með góðum starfskjörum og gódu

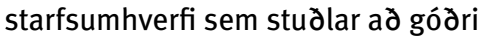
heilsu, eykur vellídan, er hvetjandi og á pátt í ad lengja starfsævina.

Vegna lýdpróunar mun pad áfram vera megináskorun til lengri tíma ad tryggja nægilegt vinnuafl á almennum og opinberum vinnumarkadi. Pad veitir fyrirtækjum á almennum vinnumarkaði ákveðin tækifæri til að auka hagvöxt og opinbera geiranum ad auka möguleika á að takast á við aukna pörf fyrir velferdarbjónustu og fjármögnun velferðarsamfélaga á Norðurlöndum í framtídinni.

Pessari áskorun fylgir mikið álag á norrænu löndin par sem atvinnupátttaka er mjög há. Aərar áskoranir eru tiltölulega miklar fjarvistir vegna veikinda á Norðurlöndum og pað hversu stór hluti íbúa par á vinnufærum aldri sem af ýmsum ástæðum stendur utan vinnumarkaðar og lifir á opinberri framfærslu.

\section{Megináskoranir fyrir stefnu í} vinnu- og vinnumarkadsmálum eru ad auka frambod vinnuafls, meðal annars með pví aə lengja starfsævina og efla pátttöku jadarhópa samfélagsins á vinnumarkaði. Petta gerir nýjar og meiri kröfur til vinnuverndar á vinnustödum fyrirtækja sem og stjórnvalda, skipulagningar vinnunnar og adlögunar vinnustaða að hverjum og einum starfsmanni. Önnur megináskorun á pessu sviði er að tryggja að starfsmenn búi yfir peirri hæfni og pekkingu sem eftirspurn er eftir á vinnumarkaði og að sífellt stærri hluti vinnuafls og peirra sem bjóda upp á pjónustu koma annars stadar ad - einnig frá löndum utan ESB og EES. 
Vegna hnattvæðingar og lýdpróunar eykst pörf fyrir erlent vinnuafl á Norðurlöndum, en auknir fólksflutningar eru einnig áskorun fyrir „norræna líkanid“. Pví getur fylgt aukid álag á ýmsa velferdarpjónustu, aukin samkeppni vardandi lág laun og tilhneiging til að sniðganga reglur um heilbrigdi og öryggi á vinnustöðum. Megináskorunin á vinnu- og vinnumarkaðssviði er ad tryggja ad farið sé ad kjarasamningum og ad félagsleg undirbod og óásættanleg starfskjör viðgangist ekki. Pað mun einnig eiga pátt í ad efla heilbrigda samkeppnisstöðu meðal fyrirtækja og launafólks á norrænum vinnumarkadi.

Pad̀ er einnig áskorun ad styrkja möguleika vinnumarkada á

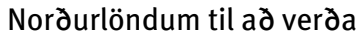
vistvænni, draga úr losun koltvísýrings og bjóda upp á vinnuafl sem býr yfir peirri hæfni sem pörf er á í nýjum greinum og á sviðum sem verda til á peim grundvelli.
Hvað varðar aukið atvinnuleysi vegna hagsveiflna munu megináskoranirnar felast í pörfá aว bregðast við meว stuttum

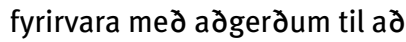
vinna bug á auknu atvinnuleysi medal ungs fólks og annarra hópa sem minna mega sín ásamt auknu langtímaatvinnuleysi, en pað getur haft alvarlegar afleiðingar fyrir hvern og einn, fyrir efnahagsstözu hins opinbera og velferdarsamfélög á Norðurlöndum. 


\section{Forgangsmál og markmið á tímabilinu}

Meginmarkmið norræns samstarfs á svidi vinnumála er à tryggja skilvirkan norrænan vinnumarkad og vinnumál á samkeppnisbærum Norðurlöndum.

Samstarf á vinnu- og vinnumarkaðssviði mun beina sjónum ad pví hvernig best megi efla jafnrétti kynjanna á vinnumarkaði og sporna gegn mismunun og óásættanlegum mismuni í starfskjörum og vinnuverndarmálum vegna kyns, skertrar starfsgetu, aldurs eða etnísks uppruna med sérstakri áherslu á adskilnad á vinnumarkadi.
Hér á eftir eru tilgreind helstu markmið samstarfs norrænu ríkisstjórnanna á tímabili áætlunarinnar fyrir sviðin vinnu- og vinnumarkaðsmál ásamt vinnuverndar- og vinnuréttarsvid.

Samstarfið verði nægilega sveigjanlegt svo unnt sé ad bregðast við hagsveiflutengdum áskorunum, kreppuástandi af ýmsum toga og hugsanlegum breytingum í pólitískum og faglegum áherslum sem gætu komid upp á pessu tímabili.

Markmiðin verða nánar útlistud íárlegum formennskuáætlunum hvers svids og í árlegum starfsáætlunum nefndanna og pemaáherslum.

\section{Vinnu- og vinnumarkaðsmál}

Forgangsmál samstarfs á svidi vinnu- og vinnumarkaðsmála er að efla framboð starfa, auka atvinnustig - ekki síst meðal ungs fólks - og draga úr atvinnuleysi vegna skipulagsbreytinga. Par mun samspil stefnu í efnahagsmálum og mennta- og vinnumarkaðsmálum skipta miklu máli. Samstarfið verður í samræmi við og um leið viðbót við ESB- og EES-samstarf á pessu svidi. 
Mikilvægustu markmið á sviði vinnu- og vinnumarkadsmála eru:

\section{Aə̉ virkja eins stóran hluta vinnuafls í löndunum og kostur er}

Áhersla verður lögdá à efla pátttöku ungs fólks, p.m.t. námsfólks, fyrr og betur, á vinnumarkadi, og um leiðá à hvetja eldra fólk til ad vera lengur á vinnumarkadi. Einnig verður lögdáhersla á ad draga úr fjarvistum starfsfólks vegna veikinda og ad auka pátttöku hópa sem hafa ekki gód tengsl við vinnumarkaðinn, p.m.t. innflytjenda og fólks med skerta starfsgetu á vinnumarkaði. Einnig parf à huga à peim sem nú pegar vinna hlutastörf og vilja auka starfshlutfall sitt.

\section{Efla samræmi milli framboðs og eftirspurnar eftir vinnuafli}

Athyglin mun beinast à pví hvernig efla má hreyfanleika á vinnumarkadi til ad draga úr flöskuhálsum og komast hjá pví, um leið og skortur er á starfsfólki innan sérstakra starfsstétta eða starfsgreina, ad margir í sama fagi eru atvinnulausir. Petta lýtur medal annars à hvatakerfum og kröfum sem snerta hvern og einn atvinnulausan og pví hvernig vinnumidlun fer fram. Gagnkvæm viðurkenning á hæfni er sem fyrr einnig mikilvægt pema.

\section{Efla símenntun sem tekur markvisst mið af pörfum vinnumarkaðarins}

Sjónum mun beint à pví hvernig best megi próa hæfni og pekkingu vinnuafls á grundvelli eftirspurnar til að tryggja að vinnuaflið búi stödugt yfir peirri hæfni sem bæði opinber og almennur vinnumarkaður kallar eftir. Almennt séd á petta við um menntun ungs fólks og hæfnipróun fullordinna en er ekki sídur mikilvægt í sambandi við markmiðið um að viðhalda tengslum eldra starfsfólks við vinnumarkaðinn svo og ad efla pátttöku hópa sem minna mega sín á vinnumarkaði.

\section{Sporna gegn atvinnuleysi meðal hópa sem standa höllum fæti og langtímaatvinnuleysi}

Áhersla mun beinast ad pví ad sporna gegn atvinnuleysi ungs fólks með skilvirkum vinnumarkaðs- og menntunarúrræðum til að efla hæfni og pátttöku á vinnumarkadi. Athyglin mun einkum beinast ad ungu atvinnulausu fólki sem hefur 
takmarkaða menntun og öərum hópum sem eiga erfitt med að fóta sig á vinnumarkadi, til dæmis innflytjendum, einstaklingum med litla menntun eda skerta starfsgetu og langtímaatvinnulausum.

\section{Auka áhuga vinnuafls utan ESB og EES á norrænum vinnumarkaði}

Áhersla mun beinast ad pví hvernig megi gera norrænan vinnumarkað eftirsóknarverðan fyrir erlent vinnuafl í löndum utan ESB og EES. Tengsl milli vaxandi fólksflutnings milli landa í atvinnuleit, hagvaxtar og sjálfbærni norrænu velferðarkerfanna eru mikilvæg í pessu samhengi til lengri tíma litið.

\section{Efla samræmingu stjórnvalda}

Lögð verður áhersla á ad efla samræmingu medal peirra stjórnvalda og stofnana sem pessir málaflokkar varða, bæði í löndunum og milli peirra, til ad auka möguleika á ad atvinnulausir, launpegar í veikindaleyfi og adrir sem eiga vid vandamál ad strída geti fljótt og skilvirkt fundið leiðir til virkrar pátttöku á vinnumarkadi.

\section{Vinnuvernd og vinnuréttur}

Eitt meginforgangsmál samstarfs á vinnuverndarsviði er ad efla öryggi, heilsu og velferdá vinnustad. Markmiðið er starfsumhverfi sem er eftirsóknarvert, hvetjandi og fyrir alla, og sem kemur í veg fyrir starfstengd heilbrigðisvandamál. Við próun pess skal jafnframt taka mið af alpjódlegum samningum og löggjöf ESB.

Eitt meginforgangsmál í samstarfi á vinnuréttarsviði er að fylgja eftir kjörum, áskorunum og adlögun norræna kerfisins, og próa pad áfram í samræmi við stöðugt hnattvæddara atvinnulíf. pad á

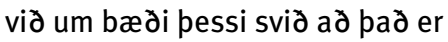
einkar mikilvægt að leggja áherslu á og efla sameiginlega reynsluog upplýsingamiðlun og byggja upp tengslanet og samhæfingu í aðgerðum og samningum innan ESB, einkum í sambandi vì innleiðingu ESB-tilskipana sem hafa pýðingu fyrir vinnuvernd og á sviði vinnuréttar.

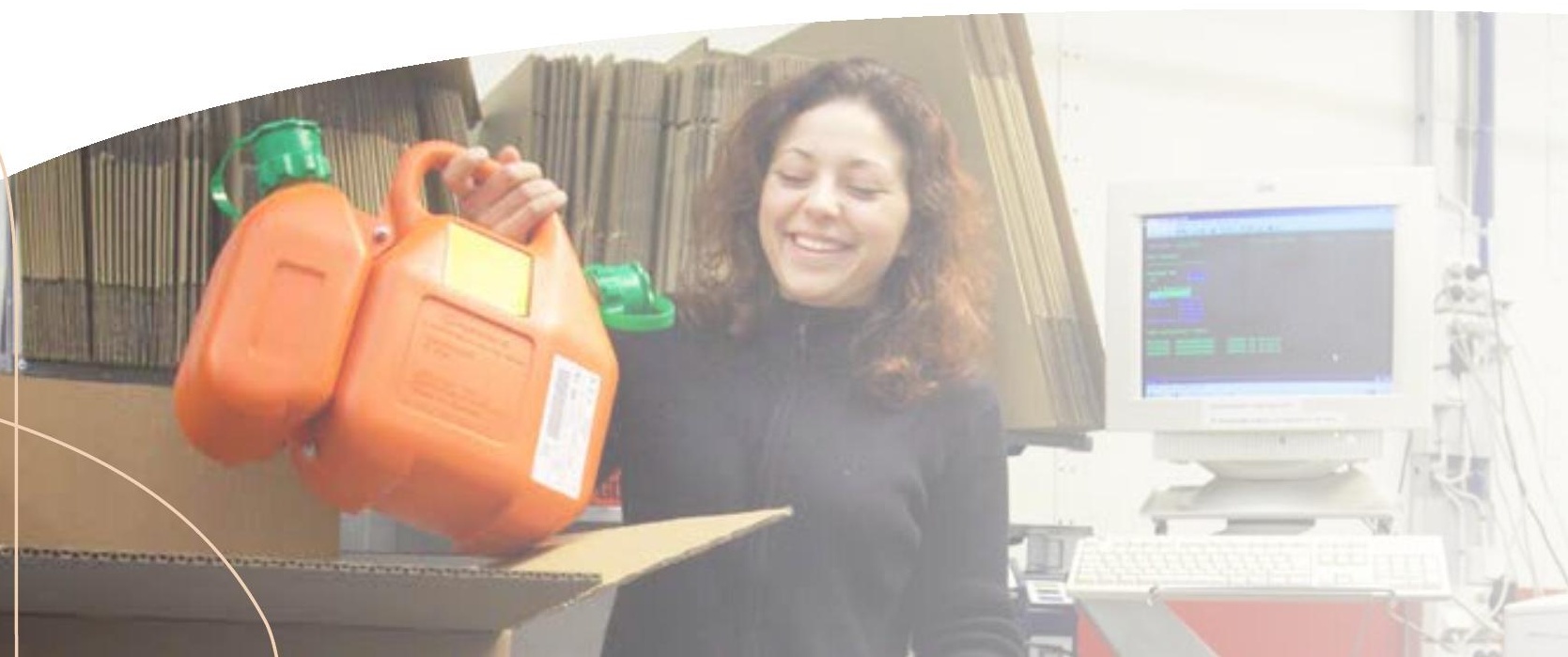




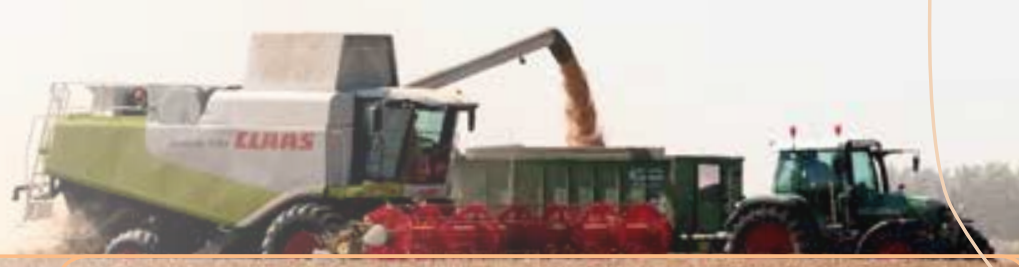

Mikilvægustu markmið samstarfs á sviði vinnuverndar og vinnuréttar eru:

\section{Aə efla líkamlega og sálræna vinnuvernd á vinnustözum}

Áherslan mun beinast ad pví ad próa og bæta adstædurá vinnustödum og er par átt við aðstæður sem snerta líkamlega, sálræna, skipulagslega og félagslega pætti. Til ad draga úr vinnuslysum og starfstengdum sjúkdómum verður lögð áhersla á kerfisbundið fyrirbyggjandi starf. Gott starfsumhverfi getur einnig verid hvati til ad lengja starfsævina. Athyglin mun medal annars beinast að peim hópum, sviðum eða starfsgreinum sem eru undir hvad mestu álagi á norrænum vinnumarkaði ásamt aðferðum til að bæta aðstæður. Önnur mikilvæg pemu eru vandamál tengd streitueinkennum sem stafa af pví ad kröfur aukast um adgengi ad starfsmönnum og pví skortir á að peir fái tækifæri til ad hvíla sig og ná sér (p.e. af streitu/ streitueinkennum).

\section{Stefnumörkun varðandi vinnuvernd og -eftirlit}

Áhersla verður lögdá áframhaldandi stefnumörkun vardandi vinnuvernd og -eftirlit par sem höfð verður hliðsjón af forgangsrödun í stefnumörkun ESB í vinnuverndarmálum og ödru alpjódlegu samstarfi á

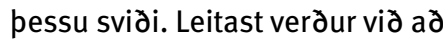
efla samstarf norrænu landanna og aðila vinnumarkadarins og ad fylgjast grannt med próun vinnuverndarmála í löndunum sem og ad bera kennsl á mikilvæg svid par sem vænta má ad̀ norrænt samstarf hafi augljóst notagildi.

\section{Vinna gegn óásættanlegum starfskjörum, félagslegu undirboði og mismunun á vinnumarkaði \\ Sjónum verdur beint à pví hvernig próa megi Norðurlönd sem eftirsóknarverðan vinnumarkað}


par sem áhersla er lögd á faglega hæfni og háa staðla varðandi starfskjör og vinnuvernd, til að laда ад pað erlenda vinnuafl sem eftirspurn er eftir. Áherslan mun jafnframt beinast ad pví ad fyrirbyggja ad aukinn innflutningur vinnuafls og láglaunasamkeppni leiði til óásættanlegra starfskjara, félagslegs undirbods og mismunun á norrænum vinnumarkadi. Pví verður reynslu af gódum aðferðum og adgerdum miðlad og einnig verdur kannad hvort unnt sé ad efla samstarf milli peirra norrænu stjórnvalda sem málid vardar.

\section{Aə upplýsa um mikilvægi góðrar stjórnunar og virkrar pátttöku starfsmanna}

Áhersla verður lögd á mikilvægi gódrar stjórnunar og virkrar pátttöku starfsmanna í próun stadla um vinnuvernd, gódrar heilsu í starfi og framleidni á vinnustöðum, jafnt á almennum vinnumarkaði og innan hins opinbera.

\section{Aə̉ nýta starfskrafta hvers og eins starfsmanns á sjálfbæran hátt}

Sjónum mun beint ad pví hvernig unnt sé ad nýta krafta hvers og eins starfsmanns á sjálfbæran hátt til ad tengja vinnu- og einkalíf á jákvæðan hátt á ólíkum skeidum lífsins, til ad draga úr streitu, fjarvistum vegna veikinda og sliti og til ad koma í veg fyrir einangrun frá vinnumarkaði og ad fólk hætti snemma ad vinna. Einnig verður hugað að sveigjanleika á vinnustöðum, meðal annars varðandi vinnutíma og fjarvinnu.

\section{Tryggja gott jafnvægi milli launpegaverndar og sveigjanleika}

Athyglin mun beinast að líkönum sem tryggja gott jafnvægi milli 
launpegaverndar og sveigjanleika meд paд ад markmiði að aдlögunarhæfni norræns vinnumarkaðar aukist enn frekar. Einnig verður

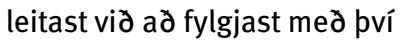

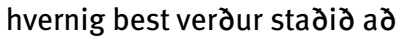
skipulagningu og framkvæmd breytinga, innleiðingu nýrra starfa og ödruvísi nýtingu vinnuafls svo komist verði hjá neikvæðum afleiðingum bæði fyrir hvern og einn, fyrirtækin og pjódhagslega.

\section{Efla norrænt samstarf varðaandi alpjódlega löggjöf}

Lögd verður áhersla á hvernig hægt er ad varðveita og próa norræna líkanið með verkaskiptingu og pekkingarmidlun og samstarfi um alpjódleg tengsl. Par er einkum átt við tengslin við ESB, Alpjódavinnumálastofnunina (ILO), Evrópurádid, Efnahagsog framfarastofnunina (OECD),
Sameinuðu pjódirnar (SP) og alpjódlegar stadlastofnanir.

\section{Forgangsmál allra sviða à meətöldu afnámi stjórnsýsluhindrana}

Sem fyrr mun pad ad fyrirbyggja og afnema stjórnsýsluhindranir vera forgangsmál allra sviða. Hverju landi ber ad leggja mat á stjórnsýsluhindranir en rádherranefndin um vinnumál (MR-A) mun einnig fylgjast náid med pessum málaflokki. Í samstarfi vid rádherranefndina um félags- og heilbrigdismál (MR-S) hefur vinnumálasvid framkvæmt gagngera kortlagningu af stjórnsýsluhindrunum á svidi félags- og vinnumarkadsmála á Norðurlöndunum. Raunverulegar stjórnsýsluhindranir skapa óparfa vanda á sameiginlegum norrænum vinnumarkaði. Með pví ad̀ ryðja hindrunum úr vegi má auka tækifæri fyrir norræna borgara til ad flytjast búferlum og hefja störf í ödru norrænu landi sem einnig mun verda til pess ad auka adgengi að hæfu vinnuafli á Norðurlöndum. Samstarfið um Evrópsku vinnumiðlunina (EURES) á landamærasvæðum er mikilvægt í pessu samhengi.

Rádherranefndin um vinnumál (MR-A) mun almennt séd taka pátt í samstarfi vid önnur svid og stofnanir á vegum Norrænu rádherranefndarinnar sem og önnur alpjódleg samtök par sem pad felur í sér norrænt notagildi. Sam-starfi við grannsvæði Norðurlanda verður haldið áfram par sem pad er mikilvægt, ad medtöldum Eystrasaltsríkjunum og Póllandi. 


\section{Rammar samstarfsins}

Frá árinu 1954 hefur

norrænt samstarf á svidi

vinnumarkadsmála byggt á

samningi um sameiginlegan

norrænan vinnumarkað sem

sídast var endurskodadur árid

1982 og ödladist gildi árid

1983. Í samningnum leggja

norrænu ríkisstjórnirnar medal

annars áherslu á ad pad séu

grundvallarréttindi borgaranna ad

vera frjálst að hefja störf og setjast

ad íödru norrænu landi. Einnig

er lögd áhersla á ad markmid

ríkisstjórnanna er à̃ viðhalda

fullri atvinnu í hverju landi fyrir

sig og aə̀ hafa um pað samstarf.

Frjáls för vinnuaflsins í norrænu

löndunum er óhád skuldbindingum

vegna samninga á ESB-svædinu

og EES. Norrænt samstarf

verður pó fyrir æ meiri áhrifum

af próun sameiginlegs evrópsk

vinnumarkaðar, en frjáls för

vinnuaflsins fellur að mestu leyti

undir reglur í samræmi við ESB-rétt

og EES-samninginn.

Á sviði vinnuverndar byggir samstarfid á norrænum

sáttmála um vinnuvernd frá

árinu 1989. Par er kveðid á um

grundvallarreglur um norrænt

samstarf á sviði vinnuverndar.

Í sáttmálanum er kveðì á um

grundvallarreglur samstarfsins, en meginmarkmið pess er að vinna

að betra, heilbrigdara og öruggara

vinnuumhverfi.

Rádherranefndin um vinnumál

(MR-A) ber meginábyrgdá

norrænu samstarfi á sviði

vinnu- og vinnumarkadsmála og

er mikilvægur vettvangur fyrir

umrædur og midlun reynslu

medal norrænna rádherra á

sviði vinnu-, vinnumarkaðs- og

vinnuverndarmála um hvernig best

sé ad takast á vid sameiginlegar

áskoranir á svidi vinnu- og

vinnumarkadsmála.

Embættismannanefnd um vinnumál (EK-A) hefur skipulag samstarfsins med höndum, hún gerir áætlun um og skiptir fjárveitingum MR-A innan sviðsins. Sveigjanleg uppbygging er mikilvæg ef norrænt samstarf á sviði vinnu- og vinnumarkadsmála á ad geta hrint í framkvæmd og fylgt eftir mikilvægum málum sem ofarlega eru á baugi hverju sinni. Embættismannanefndin um vinnumál (EK-A) hefur sett á fót prjár fastanefndir, vinnumarkaðsnefndina, vinnuverndarnefndina og vinnuréttarnefndina og skipar tímabundna (ad-hoc) starfshópa ef pess gerist pörf.
Nefndirnar og hóparnir gegna mikilvægu hlutverki fyrir miðlun reynslu milli landanna hver á sínu ábyrgðarsviði. Fastanefndirnar hafa einnig yfir ad ráda verkefnafé sem pær nota adallega til að bæta forsendur fyrir midlun á reynslu og pekkingu. pad er medal annars gert med pví ad kortleggja og greina bad sem líkt er og ólíkt í adgerdum og áhrifum peirra í löndunum. Hlutverk peirra er einnig ad leggja tillögur fyrir EK-A og MR-A,

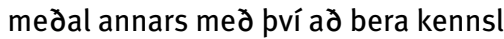
á og skapa umrædu um mikilvæg og áhugaverd pólitísk og fagleg pemu.

Á pessu tímabili er pad markmið að leggja aukna áherslu á að ræða reynslu og sameiginleg viðfangsefni.

Undir norrænt samstarf á sviði vinnumála heyrir einnig Stofnunin um framhaldsmenntun á vinnuverndarsviði (NIVA) í Helsinki, en par eru haldin námskeid og málping á ensku um vinnuverndarmál á Norðurlöndum (www.niva.org). Jafnframt fjármagnar rádherranefndin à hluta til Nordjobb-áætlunina sem er áætlun fyrir unga Norðurlandabúa sem vilja vinna sumarstörf í ödru norrænu landi (www.nordjobb.net). Rádherranefndin fjármagnar einnig upplýsingaverkefni um vinnumál á Norðurlöndunum á skandinavísku og ensku (www.arbeidslivinorden.org). 
Á eftirfarandi skipuriti má sjá stöðuna árið 2012:

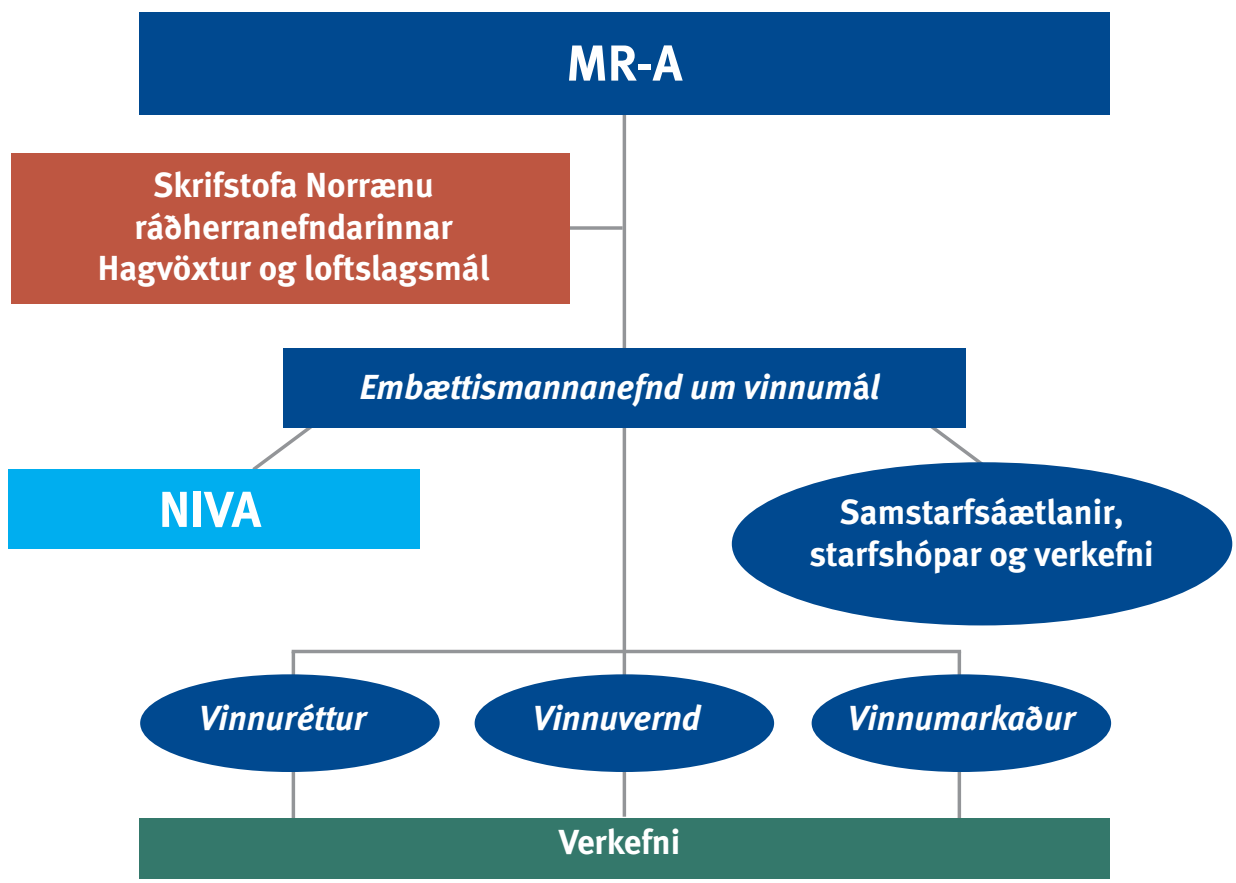

Á hverju ári leggja nefndirnar, ásamt NIVA, Nordjobb og upplýsingaverkefninu, fram starfsáætlun fyrir komandi ár ásamt ársskýrslu um niðurstöður og reikninga fyrir fyrra ár. Skipting EK-A á fjárveitingu fyrir MR-A byggist á pessum skýrslum.

Aðilar vinnumarkaðarins taka pátt í stefnumörkun á sviði vinnu- og vinnumarkadsmála og mótun norrænu velferðarsamfélaganna eru einnig mikilvægir samstarfsadilar fyrir Norrænu ráðherranefndina. Rádherranefnd um vinnumál (MR-A) og adilar vinnumarkaðarins leiða saman hesta sína á pemafundum, rádstefnum, samrádsfundum og vídar.

Lagt verður mat á framkvæmd samstarfsáætlunarinnar ádur en tímabilinu lýkur og um leid hugad aə̀ næstu samstarfsáætlun. 


\section{norden}

\section{Norræna rádherranefndin}

Ved Stranden 18

DK-1061 København K

www.norden.org

\section{Sameiginlegar áskoranir og norrænt notagildi}

Með pessari fjögurra ára samstarfsáætlun markar rádherranefnd um vinnumál stefnu og áherslur í formlegu samstarfi norrænu ríkisstjórnanna á vinnumálasviði fyrir tímabilið 2013-2016.

Á tímabilinu mun athyglin einkum beinast ad áskorunum sem norrænn vinnumarkaður stendur frammi fyrir vegna hnattvæðingar og lýdpróunar, en eftir pörfum verður einnig hugað að hagsveiflutengdum áskorunum sem koma upp á tímabilinu.

Í áætluninni koma fram meginmarkmið á sviði atvinnu- og vinnumarkaðsmála, sem og á sviði vinnuverndar og vinnuréttar, og öll miða pau að pví að takast á við pessar áskoranir. Ennfremur eru grundvöllur og rammar samstarfsins sett fram. 